\title{
Impact of season on seminal characteristics and endocrine status of adult free-ranging African buffalo (Syncerus caffer)
}

\author{
J. L. Brown ${ }^{1}$, D. E. Wildt ${ }^{2 *}$, J. R. Raath ${ }^{3}$, V. de $\operatorname{Vos}^{3}$, J. G. Howard ${ }^{2}$, \\ D. L. Janssen ${ }^{4}$, S. B. Citino ${ }^{5}$ and M. Bush ${ }^{2}$
}

${ }^{\prime}$ Department of Obstetrics and Gynecology, Uniformed Services University of the Health Sciences, Bethesda, MD 20814, USA; ${ }^{2}$ Department of Animal Health, National Zoological Park, Smithsonian Institution, Washington, DC 20008, USA, ${ }^{3}$ Kruger National Park, Skukuza 1350, Republic of South Africa; ${ }^{4}$ Department of Veterinary Services, San Diego Zoological Society, San Diego, CA, 92112, USA; ${ }^{5}$ Miami Metro Zoo, Miami, FL 33177, USA

\begin{abstract}
Summary. Pituitary, gonadal and adrenal activity were compared in free-living, adult African buffalo bulls during the breeding and nonbreeding seasons. Frequent blood samples were collected for $2 \mathrm{~h}$ from anaesthetized bulls treated intravenously with saline, gonadotrophin-releasing hormone (GnRH, $200 \mu \mathrm{g})$, human chorionic gonadotrophin (hCG, 10000 i.u.) or adrenocorticotrophic hormone (ACTH, 1.5 mg). Electroejaculates also were collected from anaesthetized bulls during the breeding and nonbreeding seasons. Pretreatment testosterone concentrations among bulls varied more during the breeding $(0 \cdot 17-23 \cdot 0 \mathrm{ng} / \mathrm{ml})$ than the nonbreeding $(0 \cdot 15-2 \cdot 21 \mathrm{ng} / \mathrm{ml})$ season. The variation within the breeding season was attributed to 8 of 25 bulls producing higher $(P<0.05)$ serum testosterone (High-T; $16.28 \pm 2.03 \mathrm{ng} / \mathrm{ml})$ and testicular $\mathrm{LH}$ receptor $(1.53 \pm 0.22 \mathrm{fmol} / \mathrm{mg}$ testis) concentrations compared with their seasonal counterparts (Low-T; $0.95 \pm 0.26 \mathrm{ng} / \mathrm{ml} ; 0.38 \pm 0.04 \mathrm{fmol} / \mathrm{mg}$ ) or with all bulls during the nonbreeding season $(0.90 \pm 0.27 \mathrm{ng} / \mathrm{ml} ; 0.31 \pm 0.04 \mathrm{fmol} / \mathrm{mg})$. The magnitude of GnRH- and hCG-induced increases in serum testosterone was similar $(P>0 \cdot 05)$ between Low- $\mathrm{T}$ bulls and bulls during the nonbreeding season. In the High-T animals treated with GnRH or hCG, serum testosterone did not increase, suggesting that secretion was already maximal. Peak serum LH concentrations after GnRH were greater $(P<0.05)$ in bulls during the nonbreeding than the breeding season; FSH responses were similar $(P>0.05)$. ACTH treatment did not increase serum cortisol concentrations above the 2-fold increase measured in bulls treated with saline, hCG and GnRH $(P>0.05)$. Ejaculate volume, sperm motility and the proportion of morphologically normal spermatozoa were greater $(P<0.05)$ during the breeding than in the nonbreeding season, but the total number of spermatozoa/ejaculate was similar $(P>0.05)$. We suggest that season effects endocrine function and seminal quality in free-living, male African buffalo. During the breeding season some, but not all, adult bulls produce high circulating concentrations of testosterone associated with increased testicular $\mathrm{LH}$ receptor binding. These findings suggest that this species may experience selective gonadal suppression, perhaps related to differences in social status.
\end{abstract}

Keywords: buffalo; LH; FSH; testosterone; testis; gonadotrophin receptors; seasonality; spermatozoa

\section{Introduction}

The extent to which season influences reproductive performance in African buffalos (Syncerus caffer) is, in part, environmentally dependent. Distinct breeding seasons have been reported for the

*Author for correspondence. 
free-ranging buffalos of Tanzania, Botswana, Uganda, the Republic of South Africa and Namibia (Fairall, 1968; Pienaar, 1969; Sinclair, 1974; Carmichael et al., 1977). In contrast, undomesticated buffalo in the rain forests of Cameroon, Zaire and Zambia calve throughout the year (Haltenorth \& Diller, 1980). Similarly, captive animals maintained in Great Britain (Zoological Gardens of London; Zuckerman, 1953) and the Republic of South Africa (National Zoological Park of Pretoria; Brand, 1963) have demonstrated no evidence of seasonal breeding activity. In instances in which seasonal breeding occurs, ovulation and conception apparently coincide with the end of the rainy season, perhaps as an adaptation to ensure adequate food availability and optimum nutritional conditions for sustaining breeding activity and pregnancy (Fairall, 1968; Pienaar, 1969; Sinclair, 1974; Carmichael et al., 1977). Buffalo in the Kruger National Park of the Republic of South Africa have a clearly demarcated breeding season, which follows the November-March rainy season. Peak mating activity is observed from February to May, and most calves are born between January and April, following a gestation of $\sim 11$ months (Fairall, 1968; Pienaar, 1969).

Part of our long-range goal is to establish a database of reproductive and endocrine characteristics in a range of free-living African wildlife species. The objective of this study was to explore the possibility of an endocrine basis for seasonal reproduction in free-living buffalos of southern Africa. We examined acute endocrine patterns and testicular gonadotrophin receptor concentrations during the breeding and nonbreeding seasons after a gonadotrophin-releasing hormone $(\mathrm{GnRH})$, human chorionic gonadotrophin (hCG) or adrenocorticotrophic hormone (ACTH) challenge. Seminal quality of ejaculates was evaluated during both seasons.

\section{Materials and Methods}

Animals and experimental protocol. The buffalos studied were from random herds free-ranging in the Kruger National Park (total estimated population, 25000 animals). Only adult bulls associated with breeding herds (60$600 \mathrm{animals} /$ herd) were examined in October-November 1988 (nonbreeding season) or April-May 1989 (breeding season). Two to 6 bulls were assessed from each herd (6-7 herds/season). All bulls were estimated to be $\sim 7$ years or older, from visual assessment and chest girth measurments (Pienaar, 1969). Animals were approached by helicopter and anaesthetized with an i.m. dart injection of 8-15 mg etorphine-HCl (M99: Reckitt \& Coleman, Hull, UK) and $50 \mathrm{mg}$ xylazine (Rompun: Bayer UK, Bury St Edmunds, Suffolk, UK); or $7 \mathrm{mg}$ carfentanil (Wildlife Laboratories. Fort Collins, CO, USA) and $50 \mathrm{mg}$ xylazine. A surgical plane of anaesthesia was maintained with supplementary anaesthetic injections. Blood samples were collected (5-min intervals for $120 \mathrm{~min}$ ) and treatments administered via an indwelling venous (jugular or saphenous) catheter. During each season, 5 animals each were given saline ( $5 \mathrm{ml}$ ), GnRH ( $200 \mu \mathrm{g}$; Cystorelin, Abbott Labs, Chicago, IL, USA) or hCG (10000 i.u.; Sigma, St Louis, MO, USA) after the third blood sample. An additional 4 animals were bled at $10-\mathrm{min}$ intervals for $120 \mathrm{~min}$ and given ACTH (1.5 mg. $150 \mathrm{u}$; Cortrosyn, Organon Inc., W. Orange, NJ, USA) after the second sample. Scrotal circumference was measured in all bulls using a flexible measuring tape. Following the last blood sample, the scrotal area was surgically prepared and an incisional biopsy technique (Burke, 1986) used to collect $\sim 350 \mathrm{mg}$ testicular parenchyma for later assessment of gonadotrophin receptors. The biopsy sample was frozen immediately on solid $\mathrm{CO}_{2}$ and stored at this temperature $\left(-79^{\circ} \mathrm{C}\right)$ until assayed. $\mathrm{M} 99$ or carfentanil anaesthesia was reversed with an i.v. injection of $24 \mathrm{mg}$ diprenorphine- $\mathrm{HCl}$ (Revivon: Reckitt \& Coleman, Hull, UK) or $700 \mathrm{mg}$ naltrexone (DuPont, Boston, MA, USA), respectively, and the xylazine was reversed with $62.5-75 \mathrm{mg}$ yohimbine (Yobine; Lloyd Laboratories, Shenandoah, IA, USA). The animals were then monitored until ataxia was absent.

All serum samples were irradiated with $60 \mathrm{kGy}$ of ${ }^{60} \mathrm{Co}$ before export to the USA to comply with US Department of Agriculture (USDA) regulations. A trial conducted before this field study indicated that such treatment had no effect on concentrations of steroid or protein hormones in sheep or rat serum (data not shown). However, irradiation did reduce gonadotrophin receptor binding by $10-50 \%$ (mean $=33 \pm 3 \cdot 3 \%$ ) in rat testis. Therefore, all radioreceptor assays were conducted on unirradiated tissues in quarantine facilities at the USDA. Plum Island Animal Disease Center (Long Island, NY, USA).

Semen collection. To determine the effect of season on ejaculate quality, semen was collected from additional bulls during the breeding $(n=6)$ and nonbreeding $(n=7)$ season. Bulls were anaesthetized as described above and electroejaculated using an electrostimulator (P-T Electronics, Boring, OR, USA) and rectal probe (Wildt et al., 1983). The probe was $55 \mathrm{~cm}$ long and $4.3 \mathrm{~cm}$ in diameter and contained 3 longitudinal electrodes. The regimented sequence consisted of 60 incremental stimuli given in 2 series. Series I and II consisted of 30 stimuli each, divided into 3 sets of 10 stimuli at 10,15 and $17 \mathrm{~V}$ (Series I) and 15,17 and $20 \mathrm{~V}$ (Series II). Ejaculates were evaluated as described by Wildt et al. (1983). 
Blood samples were obtained by venepuncture (jugular or saphenous) immediately before the onset of electroejaculation, after each electroejaculation series and at 15,30,45 and $60 \mathrm{~min}$ after the last electrical stimulus. Following the last blood sample, a testicular biopsy sample was obtained as described above.

Radioimmunoassays. All assays were validated for use with buffalo serum by demonstrating recovery of mass and parallelism between serial dilutions of pooled buffalo serum and the standard curve. The luteinizing hormone (LH) assay was developed in this laboratory and used a rabbit antiovine LH (NIH-LH-S18) antiserum (PKC-23IA), an ovine LH standard (oLH; NIH-LH-S18) and an ovine LH label (LER-1374-A) in a buffer system based on $0 \cdot 1 \mathrm{M}$ sodium phosphate $\left(\mathrm{NaPO}_{4}, \mathrm{pH} 7 \cdot 2\right)$. The custom antiserum was produced by Duncroft, Inc. (Lovettsville, VA, USA) and used at a final dilution of 1:400 000. The antiserum was specific for all LH preparations tested (NIH-LH-S18; NIH-LH-B10; canine, LER-1685-1). As estimated by relative ED $_{50}$ values, this antibody exhibited little crossreactivity with other pituitary hormones (purified ovine follicle-stimulating hormone (FSH), LER-1976-A2, 1\%; NIADDK-FSH-S17, 3.8\%; NIH-FSH-B1, 1-3\%; growth hormone, NIH-bGH-1003-A, 0.3\%; and prolactin, NIHoPr $-\mathrm{I}-2,0.0 \%$ ). Assays were incubated at $4^{\circ} \mathrm{C}$ for 6 days, adding antiserum on Day 1, labelled hormone on Day 3 and second antibody (sheep antirabbit gamma globulin) on Day 4 . Separation of free from antibody-bound hormone was achieved following addition of $1 \mathrm{ml}$ phosphate-buffered saline $(\mathrm{pH} \mathrm{7.2)}$ and centrifugation at $3000 \mathrm{~g}$ for $30 \mathrm{~min}$. The LH antiserum bound $30-40 \%$ of the ${ }^{125} 1$-labelled oLH, and the standard curve ranged from 0.016 to $4.0 \mathrm{ng} / \mathrm{tube}$ with an $\mathrm{ED}_{50}$ of $0.4 \mathrm{ng} / \mathrm{tube}$. The sensitivity, calculated as $90 \%$ of maximum binding, was $0.07 \mathrm{ng} / \mathrm{ml}$ for $200 \mu 1 \mathrm{of}$ serum. When $0.06,0.13,0.25,0.50$ or $1.00 \mathrm{ng}$ ovine LH was added to $50 \mu \mathrm{l}$ serum, $0.06,0.13,0.22,0.44$ or $1.05 \mathrm{ng}$ was recovered, respectively, after subtraction of endogenously measured hormone $(y=1 \cdot 05 \mathrm{x}-0.03 ; r=0.99)$. Inter- and intra-assay coefficients of variation were 8.9 and $7.5 \%$, respectively.

Serum FSH was measured using a radioimmunoassay previously validated for ovine serum (Brown et al., 1987) using NIADDK-FSH-S8 as the reference standard. After addition of $1 \cdot 25,2 \cdot 5,5,10,20,40$ and 80 ng ovine FSH to $50 \mu \mathrm{l}$ serum and subtraction of endogenous ligand, $1 \cdot 45,2 \cdot 29,5 \cdot 13,9 \cdot 86,20 \cdot 03,38.68$ and 78.99 ng was recovered, respectively $(\mathrm{y}=0.98 \mathrm{x}+0.04 ; r=0.99)$. Assay sensitivity was $5 \mathrm{ng} / \mathrm{ml}$ for $200 \mu \mathrm{l}$ of serum. Inter-and intra-assay coefficients of variation were 6.1 and $5.9 \%$, respectively.

Serum testosterone was measured in unextracted serum using an ${ }^{125} \mathrm{I}$ radioimmunoassay kit (ICN, Carson, CA, USA). Upon addition of $0 \cdot 1,0 \cdot 25,0.5,1 \cdot 0,2.5$ and $5 \cdot 0 \mathrm{ng}$ testosterone to $25 \mu \mathrm{l}$ serum, and after subtraction of endogenous hormone, $0.15,0.30,0.47,1 \cdot 10,2.63$ and $5.33 \mathrm{ng}$ was recovered, respectively $(\mathrm{y}=1.06 \mathrm{x} \pm 0.01$; $r=0.99$ ). Assay sensitivity was $0.1 \mathrm{ng} / \mathrm{ml}$, and the inter- and intra-assay coefficients of variation were 8.1 and $6.5 \%$, respectively.

Serum cortisol was measured using a solid-phase ${ }^{125} \mathrm{I}$ radioimmunoassay kit (Diagnostic Products, Los Angeles, CA, USA). Upon addition of $5,25,50,100$ or $250 \mathrm{ng}$ cortisol to $25 \mu \mathrm{l}$ serum, $5 \cdot 6,26 \cdot 5,51 \cdot 0,110 \cdot 1$ or $248 \cdot 7 \mathrm{ng}$ was recovered, respectively, after subtraction of endogenous hormone $(\mathrm{y}=0.99 \mathrm{x}+2.93 ; r=0.99)$. Assay sensitivity was $2 \mathrm{ng} / \mathrm{ml}$, and inter- and intra-assay coefficients of variation were 9.1 and $5.7 \%$, respectively.

Radioreceptor assays. Highly purified human chorionic gonadotrophin (hCG; 9800 i.u./mg; Radio Systems Laboratories, Carson, CA, USA) and ovine FSH (LER-1976-A2) were used as labelled ligands, and crude hCG (3225 i.u./mg; Sigma) and ovine FSH (NIADDK-FSH-S16) were used as unlabelled ligands in the LH and FSH receptor assays, respectively. LH and FSH receptors were measured in crude testicular homogenates by a standard curve technique described previously for ovine testis (Brown et al., 1987) using a pool of partly purified rat testis membranes as the reference preparation. Biopsy samples were homogenized in assay buffer with glycerol (25mM Tris-

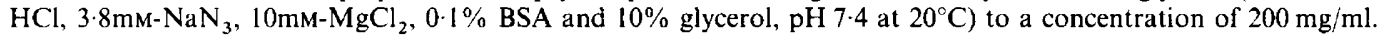
Each standard curve was constructed by incubating 200000 c.p.m. labelled hormone (in the presence or absence of excess unlabelled hormone ( $1 \mu \mathrm{g} \mathrm{hCG}$ or FSH) for determination of non-specific binding) with $1.41-120 \mathrm{mg}$ rat testis membranes (fresh tissue equivalent)/tube. Triplicate $100 \mu \mathrm{l}$ samples of buffalo testis homogenate were analysed and compared with the standard curve. Assays were incubated for $16 \mathrm{~h}$ at $20^{\circ} \mathrm{C}$ and the reaction was stopped by adding $3 \mathrm{ml}$ cold rinse buffer $\left(10 \mathrm{~mm}\right.$ Tris- $\mathrm{HCl}, 0 \cdot 154 \mathrm{M}-\mathrm{NaCl}, \mathrm{pH} 7.4$ at $\left.4^{\circ} \mathrm{C}\right)$ and centrifuging at $3500 \mathrm{~g}$ for $30 \mathrm{~min}$. Specific activities of the labelled hormones were $\sim 30$ and $5 \mu \mathrm{Ci} / \mu \mathrm{g}$ for hCG and oFSH, respectively, as determined by selfdisplacement analysis. Scatchard analyses of saturation curves were used to estimate the receptor concentration of the rat testis standard pool. For both receptor assays, parallelism was obtained between serial dilutions of rat and buffalo testis homogenate pools, suggesting that both receptor populations had similar affinities for their respective labelled ligands.

Hormone iodinations. All hormones were iodinated using low concentrations of chloramine-T for increased retention of biological activity. Other than $\mathrm{Na}-{ }^{125} \mathrm{I}$, all iodination reagents were prepared in $0 \cdot 05 \mathrm{M}-\mathrm{NaPO} \mathrm{P}_{4}(\mathrm{pH} 7 \cdot 6$ ). Ovine $\mathrm{LH}$ or ovine FSH $(5 \mu \mathrm{g} / 20 \mu \mathrm{l})$ were iodinated with $\mathrm{I} \mathrm{mCi}$ carrier-free $\mathrm{Na}^{125} \mathrm{I}(\mathrm{I} 0 \mu \mathrm{l})$ for $\mathrm{I} \mathrm{min}$ using $2 \cdot 5 \mu \mathrm{g}$ chloramine-T/10 $\mu \mathrm{l}$, and purified hCG was iodinated for $4 \mathrm{~min}$ with $1 \mu \mathrm{g}$ chloramine-T/10 $\mu \mathrm{l}$. Sodium metabisulphite $(10 \mu \mathrm{g} / 10 \mu \mathrm{l})$ was added to stop the iodination reaction. Labelled hormone was separated from free ${ }^{125} I$ using anionexchange resin (AG2-X8, 100-200 mesh, chloride form; BioRad Laboratories, Richmond, CA, USA). Columns $(1 \times 5 \mathrm{~cm})$ containing $3 \mathrm{ml}$ resin equilibrated in $0.05 \mathrm{M}-\mathrm{NaPO}_{4}(\mathrm{pH} 7.6)$ were prepared by successive elution with 2-ml samples of $0.5 \mathrm{M}, 0.05 \mathrm{M}$ with $5 \%$ BSA and $0.05 \mathrm{M}-\mathrm{NaPO}_{4}$. The reaction mixture was layered onto the column and labelled hormone eluted with $2 \mathrm{ml} 0.05 \mathrm{M}-\mathrm{NaPO}_{4}$ into a tube containing $1 \mathrm{ml}$ phosphate-buffered saline with $0 \cdot 1 \%$ gelatin ( $\mathrm{pH} \mathrm{7 \cdot 2).}$

Statistical analysis. Gonadotrophin responses to GnRH and testosterone responses to GnRH and hCG were evaluated as peak height and net area under the response curves. Data were analysed by analysis of variance. Upon 
detection of a significant treatment effect, differences among treatment groups were determined using Duncan's New Multiple Range tests or Student's $t$ tests. Data are presented as means \pm s.e.m.

\section{Results}

\section{Serum testosterone}

There was less variation in pretreatment serum testosterone concentrations among bulls during the nonbreeding season $(0 \cdot 15-2 \cdot 21 \mathrm{ng} / \mathrm{ml})$ than during the breeding season $(0 \cdot 17-23 \cdot 0 \mathrm{ng} / \mathrm{ml})$. During the latter period, bulls could be classified into 2 distinct groups based on circulating testosterone concentrations. Eight of 25 bulls produced high serum testosterone concentrations (High-T; pretreatment range $=10 \cdot 1-23.0 \mathrm{ng} / \mathrm{ml}$ ), whereas the remaining animals produced lower concentrations (Low-T; $0 \cdot 17-1 \cdot 21 \mathrm{ng} / \mathrm{ml}$ ). By chance, High-T bulls were distributed throughout the endocrine treatments (saline, $n=2$; GnRH, $n=1$; hCG, $n=1$; ACTH, $n=3$ ) and electroejaculation group $(n=1)$. Before saline or hormone treatment, mean testosterone concentration in the High-T animals $(16.28 \pm 2.03 \mathrm{ng} / \mathrm{ml})$ was greater $(P<0.05)$ than that measured in Low-T bulls $(0.95 \pm 0.26 \mathrm{ng} / \mathrm{ml})$ or in all bulls during the nonbreeding season $(0.90 \pm 0.27 \mathrm{ng} / \mathrm{ml})$. Concentrations in the last 2 groups were $\operatorname{similar}(P>0 \cdot 05)$.

Figure $1(\mathrm{a}, \mathrm{b})$ illustrates the testicular response to GnRH and hCG in the Low-T bulls during the breeding season and in all bulls during the nonbreeding season. Both treatments similarly increased testosterone secretion $(P<0.05)$ compared with saline controls, and the responses were not influenced by season $(P>0.05)$. Temporal patterns of testosterone secretion were similar $(P>0.05)$ among all High-T bulls, and neither GnRH nor hCG caused further increases in testosterone secretion. Thus, the data for High-T bulls (except the electroejaculated male) were pooled for presentation (Fig. 1c). Except for the one High-T bull, temporal patterns of testosterone secretion in all electroejaculated bulls were similar $(P>0.05)$ to those observed in saline-treated Low-T and nonbreeding-season bulls (data not shown).

\section{Serum LH and FSH}

Mean pretreatment $\mathrm{LH}$ concentrations were similar $(P>0.05)$ between High-T bulls $(3.7 \pm 0.2 \mathrm{ng} / \mathrm{ml})$ and bulls during the nonbreeding season $(3.5 \pm 0.2 \mathrm{ng} / \mathrm{ml})$. However, both of these values were greater $(P<0.05)$ than that measured in Low-T bulls $(2.6 \pm 0.2 \mathrm{ng} / \mathrm{ml})$. GnRH elicited an acute rise in serum LH in all animals, regardless of season, which was evident within 10 min of injection (Fig. 2a, b). Concentrations did not return to baseline by the end of the bleeding period in either group. Peak LH responses among bulls in the nonbreeding season ranged from 12.4 to $106.4 \mathrm{ng} / \mathrm{ml}$ compared with $26.5 \mathrm{ng} / \mathrm{ml}$ for the only High-T bull and from 5.6 to $10.9 \mathrm{ng} / \mathrm{ml}$ for the Low-T bulls during the breeding season. The total amount of LH secreted following GnRH was 3 times greater $(P<0.05)$ during the nonbreeding than the breeding season.

In contrast to $\mathrm{LH}$, mean pretreatment FSH concentrations were greater $(P<0.05)$ in High-T bulls $(43.9 \pm 4.1 \mathrm{ng} / \mathrm{ml})$ than in Low-T bulls $(29.2 \pm 2.5 \mathrm{ng} / \mathrm{ml})$ or animals sampled during the nonbreeding season $(31.9 \pm 2.2 \mathrm{ng} / \mathrm{ml})$. There was no difference $(P>0.05)$ in $\mathrm{GnRH}$-stimulated FSH secretion between the breeding and nonbreeding season. GnRH increased FSH concentrations by $30-40 \%$ over those of saline-treated controls (Fig. $2 \mathrm{c}, \mathrm{d}$ ).

\section{Serum cortisol}

Season had no influence $(P>0.05)$ on temporal patterns of cortisol secretion in saline- or ACTH-treated bulls (Fig. 3). Within season, cortisol secretion was similar $(P>0.05)$ among saline-, GnRH- and hCG-treated and electroejaculated animals, concentrations increasing more than 2 -fold in all groups. Administering ACTH failed $(P>0.05)$ to elicit a cortisol response 

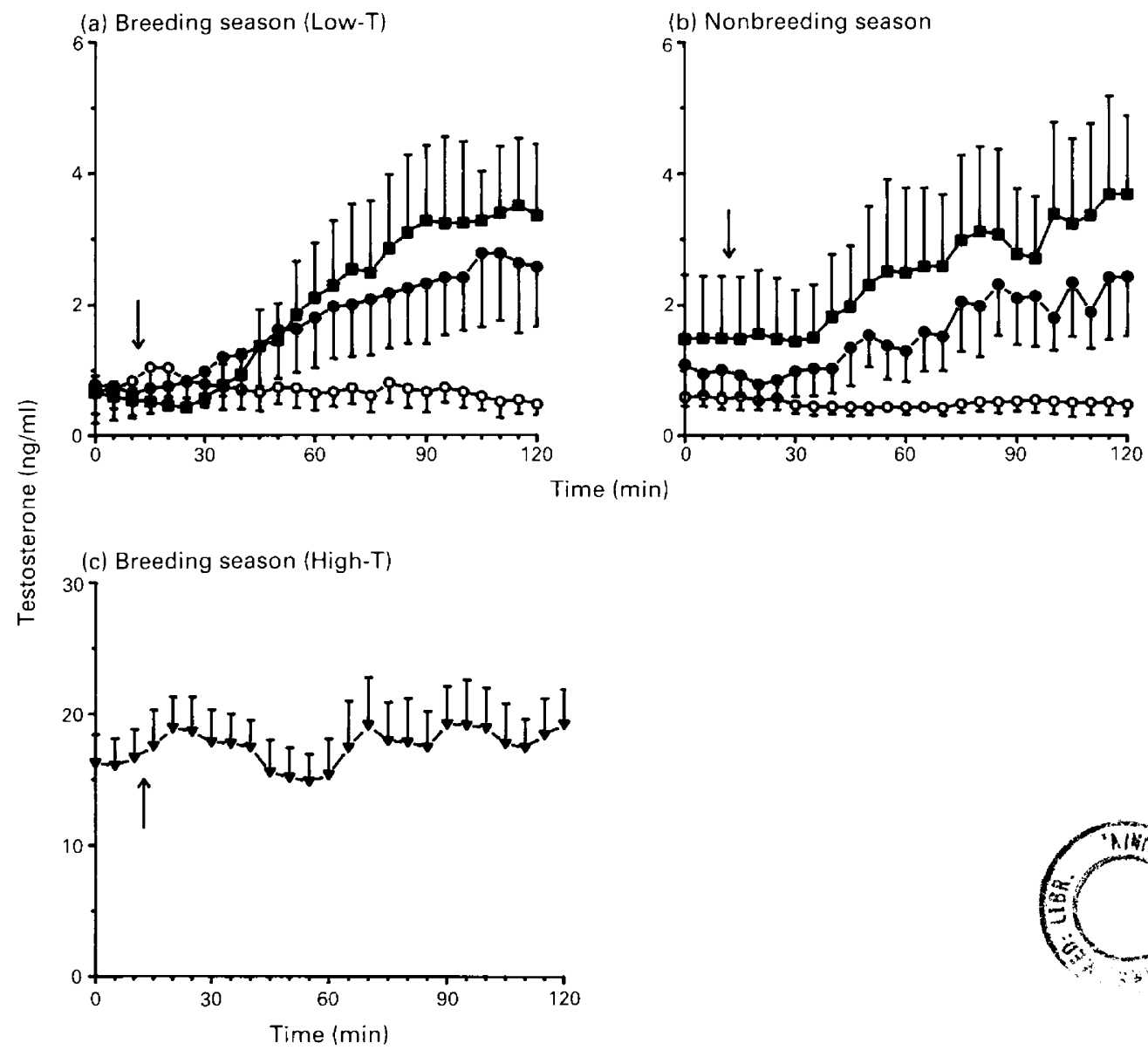

Fig. 1. Concentrations of serum testosterone in (a) low-testosterone buffalo bulls (Low-T; see text for details) during the breeding season and (b) males during the non breeding season. Bulls were injected i.v. with saline $(O ; n=3)$, human chorionic gonadotrophin $(\mathbf{O} ; n=4)$ or gonadotrophin-releasing hormone $(\mathbf{\square} ; n=4)$. Data for high-testosterone bulls (High-T), pooled within treatment groups $(n=7)$, are represented in (c). Time of treatment administration is indicated by the arrows. Values are means \pm s.e.m.

greater than that observed in the other treatment groups and had no effect $(P>0.05)$ on circulating concentrations of testosterone, $\mathrm{LH}$ or FSH (data not shown). There also were no differences $(P>0.05)$ in temporal patterns of cortisol secretion between High- and Low-T bulls.

\section{Testicular LH and FSH receptors}

Concentrations of testicular LH and FSH receptors were unaffected $(P>0.05)$ by saline, GnRH, hCG or ACTH treatment or by the electroejaculation procedure. Therefore, the data in Fig. 4 were pooled among these groups for presentation. There was a greater $(P<0.05)$ concentration of LH receptors in bulls during the breeding than the nonbreeding season (Fig. 4a). However, this difference was due exclusively to a 4-fold increase $(P<0.05)$ in receptor concentrations observed in the High-T group. LH receptor concentrations were similar $(P>0.05)$ between Low-T bulls and bulls during the nonbreeding season. In contrast, there were no differences $(P>0.05)$ in 

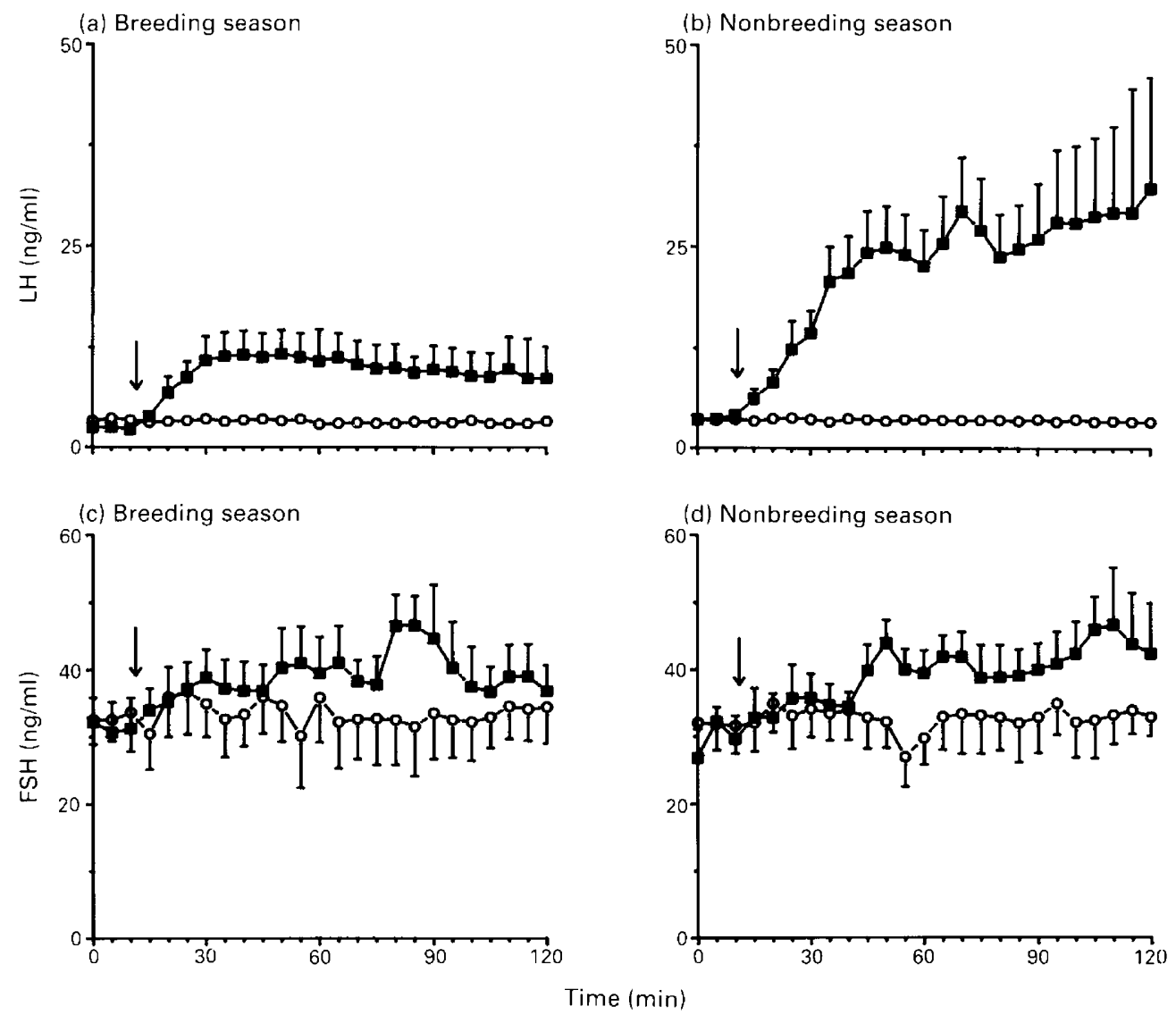

Fig. 2. Concentrations of serum luteinizing hormone $(\mathrm{LH} ; \mathrm{a}, \mathrm{b})$ and follicle-stimulating hormone (FSH; c, d) in buffalo bulls during the breeding and nonbreeding season, respectively. Bulls were treated with saline $(O ; n=5)$ or gonadotrophin-releasing hormone $(\mathbf{\square} ; n=5)$ i.v. Time of treatment administration is indicated by the arrows. Values are means \pm s.e.m.

FSH receptor concentrations either on the basis of season or circulating testosterone concentrations (Fig. 4b).

\section{Scrotal circumference and seminal characteristics}

The mean scrotal circumference of High-T bulls $(48.6 \pm 1.4 \mathrm{~cm})$ was greater $(P<0.05)$ than that of Low-T bulls $(39.1 \pm 1.0 \mathrm{~cm})$ or bulls evaluated during the nonbreeding season $(42.2 \pm 1.3 \mathrm{~cm})$. Although the total number of spermatozoa/ejaculate was similar $(P>0.05)$ between seasons, bulls during the breeding season produced ejaculates with a greater $(P<0.05)$ volume and lower $(P<0.05)$ sperm concentration than did bulls evaluated during the nonbreeding season (Table 1). The mean percentage of motile and morphologically normal spermatozoa was lower $(P<0.05)$ in ejaculates collected during the nonbreeding season. The most prevalent sperm abnormalities involved the presence of cytoplasmic droplets and deformities of the midpiece and flagellum. Seminal quality of the one High-T bull ( $2 \mathrm{ml}$ volume; $304 \times 10^{6}$ concentration; $75 \%$ motility; $92 \%$ normal spermatozoa) was unremarkable compared with the average of all bulls evaluated during the breeding season. 
(a) Breeding season

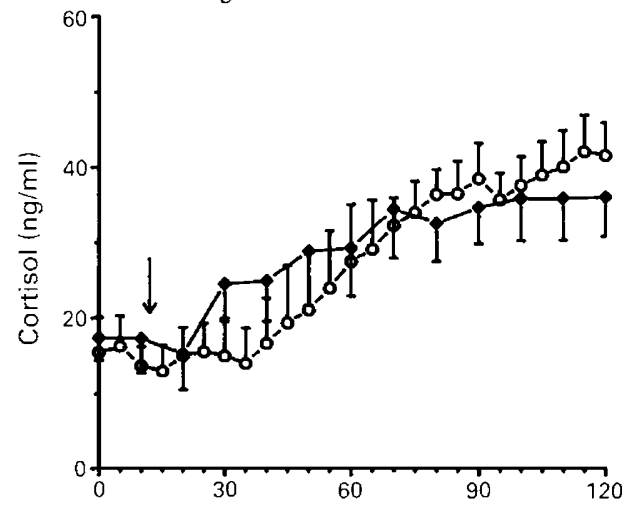

(b) Nonbreeding season

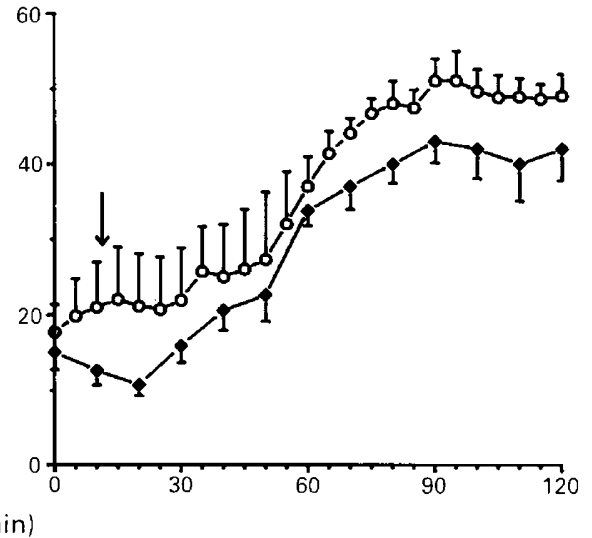

Fig. 3. Concentrations of serum cortisol during the (a) breeding and (b) nonbreeding seasons in buffalo bulls treated with saline $(O ; n=5)$ or adrenocorticotrophic hormone $(\diamond ; n=4)$ i.v. Time of treatment administration is indicated by the arrows. Values are means \pm s.e.m.

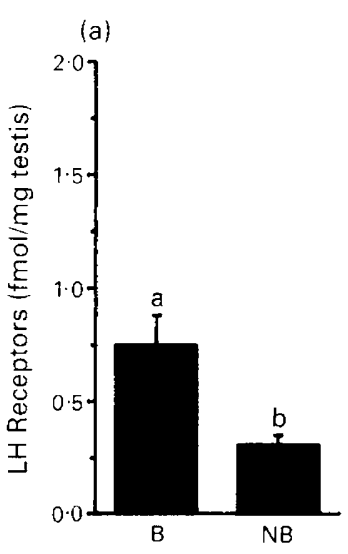

All

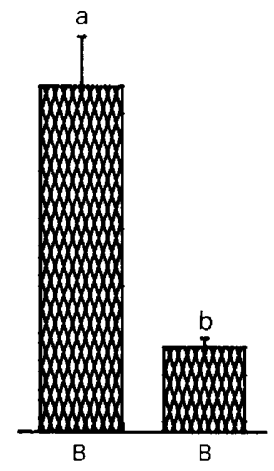

High-T Low-T

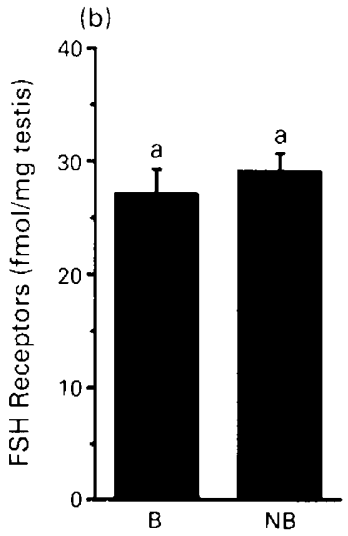

All

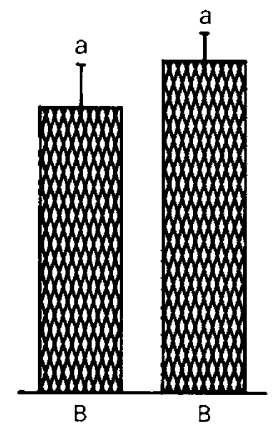

High-T Low-T

Fig. 4. Concentrations of testicular (a) luteinizing hormone (LH) and (b) follicle-stimulating hormone (FSH) receptors in all buffalo bulls during the breeding $(\mathrm{B} ; n=25)$ and nonbreeding (NB; $n=26)$ seasons (solid bars) and in the High-T $(n=8)$ and Low-T bulls $(n=17)$ (see text for details) during the breeding season (hatched bars). ${ }^{\text {a, b}}$ Values bearing different superscripts within each receptor class are different $(P<0.05)$. Values are means \pm s.e.m.

\section{Discussion}

African buffalos belong to the family Bovidae, as do antelopes. The timing of sexual activity in buffalos and most antelopes is strongly influenced by seasonal rainfall patterns, which dictate the availability and quality of food (Gosling, 1986). Therefore, whereas seasonal breeding in ungulates such as sheep (Lincoln, 1978; Karsch et al., 1984; Sandford et al., 1984) and deer (Mirarchi et al., 1978; Lincoln \& Kay, 1979; Asher et al., 1989) is primarily under photoperiodic control, other factors including rainfall, food supply and temperature appear to be of overriding importance in African bovids (Gosling, 1986). 
Table 1. Ejaculate characteristics of free-ranging African buffalo during the breeding and nonbreeding seasons

\begin{tabular}{lcc}
\hline & $\begin{array}{c}\text { Breeding season } \\
(n=6)\end{array}$ & $\begin{array}{c}\text { Nonbreeding season } \\
(n=7)\end{array}$ \\
\hline Ejaculate volume $(\mathrm{ml})$ & $22 \cdot 2 \pm 4 \cdot 7$ & $11 \cdot 1 \pm 2 \cdot 6^{*}$ \\
Sperm concentration/ml $\left(\times 10^{-6}\right)$ & $461 \cdot 5 \pm 70 \cdot 7$ & $1011 \cdot 0 \pm 183 \cdot 4^{*}$ \\
Total spermatozoa/ejaculate $\left(\times 10^{-9}\right)$ & $11 \cdot 4 \pm 3 \cdot 7$ & $9 \cdot 9 \pm 3 \cdot 3$ \\
Motility $(\%)$ & $81 \cdot 7 \pm 1 \cdot 7$ & $68.8 \pm 6 \cdot 7^{*}$ \\
Normal spermatozoa $(\%)$ & $91 \cdot 3 \pm 0 \cdot 9$ & $75 \cdot 6 \pm 9 \cdot 4^{*}$ \\
Sperm abnormalities $(\%)$ & $3 \cdot 1 \pm 0 \cdot 5$ & $5 \cdot 0 \pm 1 \cdot 4$ \\
$\quad$ Abnormal acrosome & $0 \cdot 6 \pm 0 \cdot 3$ & $1 \cdot 1 \pm 0.4$ \\
Proximal cytoplasmic droplet & $0 \cdot 7 \pm 0 \cdot 4$ & $3 \cdot 3 \pm 2 \cdot 1$ \\
Distal cytoplasmic droplet & $2 \cdot 1 \pm 0 \cdot 5$ & $6 \cdot 9 \pm 4 \cdot 0$ \\
Bent midpiece with cytoplasmic droplet & $1 \cdot 4 \pm 0 \cdot 6$ & $6 \cdot 2 \pm 4 \cdot 6$ \\
Coiled flagellum & $0 \cdot 8 \pm 0 \cdot 3$ & $1 \cdot 7 \pm 0 \cdot 9$ \\
Bent flagellum & & \\
\hline
\end{tabular}

*Different from corresponding value during the breeding season $(P<0.05)$.

This study identifies a seasonal influence on several components of reproductive function in buffalo bulls free-ranging in southern Africa. The most striking observation was that a subpopulation of bulls $(32 \%)$ secreted extremely high concentrations of testosterone (High-T) compared with other bulls during the breeding season (Low-T) or with bulls during the nonbreeding season. Steroidogenic activity in these High-T bulls appeared to be maximal, because neither hCG nor GnRH treatment induced any further increases in testosterone secretion. The reasons for this difference in testosterone secretion are unknown, but they may be related to physical, social and/or environmental factors. Buffalo bulls are considered sexually mature at $2 \cdot 5-3$ years of age, but rarely participate in breeding until 7-8 years of age (Pienaar, 1969). All bulls in this study appeared to be at least 7 years of age, suggesting that age probably was not the cause for the differences observed between these 2 groups. Nutritional factors associated with herd location (e.g. availability and quality of food and water) also can be eliminated, because High-T and Low-T bulls were present in the same herds. An alternative explanation may be related to differences in social status. Serum testosterone concentrations are known to be higher in territorial, socially dominant male impala (Aepyceros melampus) (Bramley \& Neaves, 1972; Illius et al., 1983) and blesbok (Damaliscus dorcas) (Illius et al., 1983) than in their subordinant counterparts. In addition, positive correlations between social status and androgen concentrations have been observed in a wide variety of other ungulate families including cervids (red deer, Cervus elaphus: Lincoln et al., 1972; white-tailed deer, Odocoileus virginianus: Miller et al., 1987), equids (plains zebra, Equus burchelli and Grevy's zebra, E. grevyi: Chaudhuri \& Ginsberg, 1990) and African elephants (Loxodonta africana: Poole et al., 1984). Breeding strategies vary considerably among free-living African bovids, but the formation of male dominance hierarchies appears to be a common social adaptation (Jarman, 1974; Jarman \& Jarman, 1979). Furthermore, behavioural studies suggest that male buffalos develop a dominance hierarchy within both breeding and bachelor herds (Jarman, 1974; Sinclair, 1974; Jarman \& Jarman, 1979; Mloszewski, 1983). Although these high-ranking bulls may not be the only ones that breed, they apparently service more females at peak oestrus (Mloszewski, 1983). We speculate that, by chance, our breeding-season group consisted of both socially dominant and subordinate males. These data would therefore suggest that there may be an endocrinological basis to dominance in buffalos.

In this study, the high testosterone secretion in High-T bulls was associated with increased concentrations of testicular LH receptors as well as an increase in testis size and basal concentrations of serum $\mathrm{LH}$ and $\mathrm{FSH}$. Increases in testicular $\mathrm{LH} / \mathrm{hCG}$ receptor binding during the breeding season in the mongoose (Herpestes auropunctatus) (Soares \& Hoffman, 1982a) and sheep (Barenton \& Pelletier, 1983), or experimentally induced stimulatory photoperiods in hamsters (Bartke et al., 1982) and bank voles (Clethrionomys glareolus) (Tahka \& Rajaniemi, 1985) have 
been related to increased androgen production (Bartke et al., 1982; Barenton \& Pelletier, 1983; Tahka \& Rajaniemi, 1985). These results are therefore consistent with findings that seasonal patterns of testosterone secretion are due, in part, to altered testicular sensitivity to $\mathrm{LH}$.

Secretion of $\mathrm{LH}$ in response to $\mathrm{GnRH}$ was considerably less during the breeding than the nonbreeding season. Such reductions in pituitary sensitivity have been reported for sheep (Lincoln, 1978; Sanford et al., 1984) and deer (Lincoln \& Kay, 1979; van Mourik et al., 1986). Conversely, seasonal increases in pituitary responsiveness have been reported for the mongoose (Soares $\&$ Hoffman, 1982b) and horse (Clay et al., 1989). Some of the apparent differences observed in pituitary sensitivity to GnRH may be due to the timing of the challenge (early, mid or late breeding season) rather than to actual species differences. Studies in sheep suggest that GnRH-induced LH release is greatest just before or during the early breeding season (Sanford et al., 1984; Suttie et al., 1989). In addition, observations in deer, sheep and rock hyrax (Procavia capensis) suggest that maximal pituitary LH concentrations occur during the phase of redevelopment, rather than coincident with maximum testicular size (Lincoln, 1981; Millar \& Glover, 1973). Furthermore, a decline in pituitary LH during the late breeding season in the rock hyrax has been attributed to a depletion of pituitary stores due to a concomitant increase in gonadotrophin secretion (Millar \& Glover, 1973). In this study, buffalo bulls were evaluated during the later part of their breeding season, which probably explains our results. The data regarding pituitary responsiveness in High-T bulls is equivocal since only one male was evaluated in this group. However, it appears that differences in pituitary function may also exist during the breeding season, because this High-T bull exhibited an LH response $2 \cdot 5$ times greater than that observed in the Low-T bulls.

The lack of a seasonal effect in cortisol secretion is consistent with reports for goats (Howland et al., 1985) and white-tailed deer (Bubenik et al., 1975). Initial concentrations of serum cortisol were similar to those reported for other African ungulate species (Schiewe et al., 1988). However, in contrast to that study, anaesthesia alone elicited a significant increase in cortisol secretion equal to that observed following ACTH. Apparent species differences in the magnitude of adrenal responsiveness to manipulatory procedures have been reported by Wildt et al. (1988) for nondomestic felids. In that study, anaesthesia alone or anaesthesia plus electroejaculation elicited maximal cortisol secretion in tigers and leopards, but not in cheetahs and pumas, when compared with the responses observed following ACTH treatment.

Overall ejaculate quality, as determined by estimates of total spermatozoa/ejaculate, sperm motility and structurally normal spermatozoa were within the normal ranges reported for domestic cattle (Foote, 1980). The causes of seasonal differences in ejaculate volume and concentration are not known, but were probably not due to procedural differences since the electroejaculation regimen and persons operating both the probe and electroejaculator were the same for both seasons. Instead, greater ejaculate volume during the breeding season was probably due to an increase in the secretory activity of the accessory sex glands as described for the black wildebeest (Connochaetes gnou) and red hartebeest (Alcelaphus buselaphus) (Skinner et al., 1973). Although the percentages of motile and morphologically normal spermatozoa were both reduced during the nonbreeding season, the finding of similar numbers of spermatozoa per ejaculate indicated that buffalo testes are capable of maintaining spermatogenic activity throughout the year. These latter data contrast somewhat to studies of other African bovids (impala; blesbok; greater kudu, Tragelaphus strepsiceros; springbok, Antidorcas marsupialis: Skinner, 1971; black wildebeest and red hartebeest: Skinner et al., 1973) in which sperm production, as measured by epididymal reserves, are reduced $30-90 \%$ during the nonbreeding season. However, our motility data support the assertion that this parameter is compromised by season in many African bovids, although the $18 \%$ reduction in motility measured in this study was not as profound as that reported in other species (Skinner, 1971; Skinner et al., 1973). Seminal quality did not appear to differ between High-T and Low-T bulls, because ejaculate characteristics in the one High-T electroejaculated bull were not greater than those of its Low-T counterparts. However, more data are required before significant conclusions can be made regarding the lack of seminal quality differences between Low- and High-T bulls. 
Our observations document, for the first time, that there is a seasonal difference in ejaculate characteristics of free-living, African buffalo bulls and a striking demarcation in endocrine status among bulls during the breeding season. These results suggest that there may be a close relationship between endocrine function and the social hierarchy of adult buffalo bulls. The relevance of these observed endocrine differences to the determination of male social ranking now awaits studies correlating endocrine data with behavioural dominance.

We thank Dr J. A. Dias for the FSH antiserum ( $\$ 178)$; Dr L. E. Reichert, Jr for the iodinationgrade ovine LH and FSH; the NIADDK for the ovine LH and FSH standard preparations; Dr D. Keet, Dr D. Grobler and J. Malan for assistance in all field operations; P. Otto and H. Nierkirk for piloting the helicopters; Dr H. van der Watt and T. A. du Plessis (Isoster, Kempton Park, RSA) for irradiating the serum samples; Dr G. Genovesi, D. Gerstner and B. Rodd for providing the facilities at Plum Island for the radioreceptor analyses; M. Nelson and A. Mitchell for excellent technical assistance; and J. Z. Koeser for secretarial support. This study was supported, in part, by Friends of the National Zoo (FONZ), the Ringling Brothers and Barnum and Bailey Circus, and the New Opportunities for Animal Health Sciences (NOAHS) Center. Blood samples were collected in full compliance with specific US Fish and Wildlife permits issued to the National Zoological Park, Smithsonian Institution.

\section{References}

Asher, G.W., Peterson, A.J. \& Bass, J.J. ( 1989) Seasonal pattern of $\mathbf{L H}$ and testosterone secretion in adult male fallow deer, Dama dama. J. Reprod. Fert. 85, 657-665.

Barenton, B. \& Pelletier, J. (1983) Seasonal changes in testicular gonadotropin receptors and steroid content in the ram. Endocrinology 112, 1141-1146.

Bartke, A., Klemcke, H.G., Amador, A. \& Van Sickle, M. (1982) Photoperiod and regulation of gonadotropin receptors. Ann. NY Acad. Sci. 383, 122-134.

Bramley, P.S. \& Neaves, W.B. (1972) The relationship between social status and reproductive activity in male impala, Aepyceros melampus. J. Reprod. Fert. $31,77-81$.

Brand, D.J. (1963) Records of mammals bred in the National Zoological Gardens of South Africa during the period 1908 to 1960. Proc. Zool. Soc. Lond. 140, $617-659$.

Brown, J.L., Stuart, L.D. \& Chakraborty, P.K. (1987) Endocrine profiles, testicular gonadotropin receptors and sperm production in hemi-castrated ram lambs. J. Anim. Sci. 65, 1563-1570.

Bubenik, G.A., Bubenik, A.B., Brown, G.M., Trenkle, A. \& Wilson, D.I. (1975) Growth hormone and cortisol levels in the annual cycle of white-tailed deer (Odocoileus virginianus). Can. J. Physiol. Pharmac. 53, 787-792.

Burke, T.J. (1986) Testicular biopsy. In Small Animal Reproduction and Infertility, a Clinical Approach to Diagnosis and Treatment, pp. 140-146. Ed. T. J. Burke. Lea \& Febiger, Philadelphia.

Carmichael, I.H., Patterson, L., Drager, N. \& Breton, D.A. (1977) Studies on reproduction in the African buffalo (Syncerus caffer) in Botswana. S. Afr. J. Wildl. Res. 7, 45-52.

Chaudhuri, M. \& Ginsberg, J.R. (1990) Urinary androgen concentrations and social status in two species of free-ranging zebra (Equus burchelli and E. grevili). $J$. Reprod. Fert. 88, 127-133.

Clay, C.M., Squires, E.L., Amann, R.P. \& Nett, T.M. (1989) Influences of season and artificial photoperiod on stallions: pituitary and testicular responses to exogenous GnRH. J. Anim. Sci. 67, 763-770.

Fairall, N. (1968) The reproductive seasons of some mammals in the Kruger National Park. Zool. Afric. 3, $189-210$.

Foote, R.H. (1980) Artificial insemination. In Reproduction in Farm Animals, 4th Edn, pp. 521-545. Ed. E. S. E. Hafez. Lea \& Febiger, Philadelphia.

Gosling, L.M. (1986) The evolution of mating strategies in male antelopes. In Ecological Aspects of Social Evolution: Birds and Mammals, pp. 244 280. Princeton University Press, New Jersey.

Haltenorth, T. \& Diller, H. (1980) Even-toed ungulates. Artiodactyla. In $A$ Field Guide to the Mammals of Africa including Madagascar, pp. 106-108. Collins, London.

Howland, B.E., Sanford, L.M. \& Palmer, W.M. (1985) Changes in serum levels of LH, FSH, prolactin, testosterone and cortisol associated with season and mating in male pygmy goats. $J$. Androl. 6, 89-96.

Illius, A.W., Haynes, N.B., Lamming, G.E., Howles, C.M., Fairall, N. \& Millar, R.P. (1983) Evaluation of LH-RH stimulation of testosterone as an index of reproductive status in rams and its application in wild antelope. J. Reprod. Fert. 68, 105-112.

Jarman, P.J. (1974) The social organisation of antelope in relation to their ecology. Behaviour 48, 215-267.

Jarman, P.J. \& Jarman, M.V. (1979) The dynamics of ungulate social organization. In Serengeti: Dyanamics of an Ecosystem, pp. 185-220. Eds A. R. E. Sinclair \& M. Norton-Griffiths. University of Chicago Press, Chicago. 
Karsch, F.J., Bittman, E.L., Foster, D.L., Goodman, R.L., Legan, S.J. \& Robinson, J.E. (1984) Neuroendocrine basis of seasonal reproduction. Recent Prog. Horm. Res. 40, 185-232.

Lincoln, G.A. (1978) The temporal relationship between plasma levels of FSH and LH in the ram. $J$. Reprod. Fert. 53, 31-37.

Lincoln, G.A. (1981) Seasonal aspects of testicular function. In The Testis, pp. 255-302. Eds. H. Burger \& D. de Kretser. Raven Press, New York.

Lincoln, G.A. \& Kay, N.B. (1979) Effects of season on the secretion of $\mathrm{LH}$ and testosterone in intact and castrated red deer stags (Cervus elaphus). J. Reprod. Fert. 55, 75-80.

Lincoln, G.A., Guinness, F. \& Short, R.V. (1972) The way in which testosterone controls the social and sexual behaviour of the red deer stag (Cervus elaphus). Horm. Behav. 3, 375-396.

Millar, R.P. \& Glover, T.D. (1973) Regulation of seasonal sexual activity in an ascrotal mammal, the rock hyrax, Procavia capensis. J. Reprod. Fert., Suppl. 19, 203-220.

Miller, K.V., Marchington, R.L., Forand, K.J. \& Johansen, K.L. (1987) Dominance, testosterone levels and scraping activity in a captive herd of white-tailed deer. J. Mammal. 68, 812-817.

Mirarchi, R.E., Howland, B.E., Scanlon, P.F., Kirkpatrick, R.L. \& Sanford, L.M. (1978) Seasonal variation in plasma $\mathrm{LH}$, FSH, prolactin and testosterone concentrations in adult male white-tailed deer. Can. J. Zool. 56, 121-127.

Mloszewski, M.J. (1983) Hierarchy, status and individual specialization. In The Behavior and Ecology of the African Buffalo, pp. 121-137. Cambridge University Press, New York.

Pienaar, U. de V. (1969) Observations on developmental biology, growth and some aspects of the population ecology of African buffalo (Syncerus caffer caffer, Sparrman) in the Kruger National Park. Koedoe 12, $29-52$.

Poole, J.H., Kasman, L.H., Ramsey, E.C. \& Lasley, B.L. (1984) Musth and urinary testosterone concentrations in the African elephant (Loxodonta afri(ana). J. Reprod. Fert. 70, 255-260.

Sanford, L.M., Howland, B.E. \& Palmer, W.M. (1984) Seasonal changes in the endocrine responsiveness of the pituitary and testes of male sheep in relation to their patterns of gonadotropic hormone and testosterone secretion. Can. J. Physiol. 62, 827-833.

Schiewe, M.C., Bush, M., Phillips, L.P. \& Wildt, D.E. (1988) Variables influencing the collection and cryo- preservation of embryos from nondomestic ungulate species. Proc. IIth Int. Cong. Anim. Reprod. \& AI (Dublin) 2, 190a-c.

Sinclair, A.R.E. (1974) The natural regulation of buffalo populations in East Africa. II. Reproduction, recruitment and growth. E. Afr. Wildl. J. 12, 169-183.

Skinner, J.D. (1971) The effect of season on spermatogenesis in some ungulates. J. Reprod. Fert., Suppl. 13, 29-37.

Skinner, J.D., Van Zyl, J.H.M. \& Van Heerden, J.A.H. (1973) The effect of season on reproduction in the black wildebeest and red hartebeest in South Africa. J. Reprod. Fert., Suppl. 19, 101-110.

Soares, M.J. \& Hoffman, J.C. (1982a) Seasonal reproduction in the mongoose, Herpestes auropunctatus. II. Testicular responsiveness to luteinizing hormone. Gen. Comp. Endocr. 47, 226-234.

Soares, M.J. \& Hoffman, J.C. (1982b) Seasonal reproduction in the mongoose, Herpestes auropunctatus. III. Regulation of gonadotropin secretion in the male. Gen. Comp. Endocr. 47, 235-242.

Suttie, J.M., Fennessy, P.F., Corson, I.D., Laas, F.J., Elgar, H.J. \& Lapwood, K.R. (1989) L.H and testosterone responses to $\mathrm{GnRH}$ in red deer (Cervus elaphus) stags kept in a manipulated photoperiod. $J$. Reprod. Fert. 85, 213-219.

Tahka, K.M. \& Rajaniemi, H. (1985) Photoperiodic modulation of testicular $\mathrm{LH}$ receptors in the bank vole (Clethrionomys glareolus). J. Reprod. Fert. 75, 513-519.

Van Mourik, S., Stelmasiak, T. \& Outch, K.H. (1986) Seasonal variation in plasma testosterone, luteinizing hormone concentrations and LH-RH responsiveness in mature, male rusa deer (Cervus rusa timorensis). Comp. Biochem. Phys. 83A, 347-351.

Wildt, D.E., Bush, M., Howard, J.G., O'Brien, S.J., Meltzer, D., van Dyk, A., Ebedes, H. \& Brand, D.J. (1983) Unique seminal quality in the South African cheetah and a comparative evaluation in the domestic cat. Biol. Reprod. 29, 1019-1025.

Wildt, D.E., Phillips, L.G., Simmons, L.G., Chakraborty, P.K., Brown, J.L., Howard, J.G., Teare, A. \& Bush, M. (1988) A comparative analysis of ejaculate and hormonal characteristics of the captive male cheetah, tiger, leopard and puma. Biol. Reprod. 38, 245-255.

Zuckerman, C.B. (1953) The breeding seasons of mammals in captivity. Proc. Zool. Soc. Lond. 122, $827-950$.

Received 28 April 1990 